\title{
Antioxidant ability of alcoholic infusions from vegetable raw materials
}

\section{Oleg Kuzmin'1, Volodymyr Kucherenko², Nataliia Stukalska1, Anatolii Kuts ${ }^{1}$, Svitlana Oliynyk ${ }^{1}$, Djamal Rakhmetov ${ }^{3}$}

\author{
1 - National University of Food Technologies, Kyiv, Ukraine \\ 2 - Ukrainian Corporation for Viticulture and Wine Industry "Ukrvinprom" \\ 3 - M.M. Gryshko National Botanic Garden of NAN of Ukraine, Kyiv, Ukraine
}

\section{Keywords:}

Alcohol

Beverage

Antioxidant

Redox

Infusion

Article history:

Received 21.01.2020

Received in revised

form 20.07.2020

Accepted

27.12.2020

Corresponding

author:

Oleg Kuzmin

E-mail:

kuzmin_ovl@ukr.net

DOI:

$10.24263 / 2304-$

974X-2020-9-4-6

\section{Abstract}

Introduction. The aim of the study is to develop the scientific bases of antioxidant activity of water-alcohol infusions from vegetable raw materials and to identify the most promising plants as sources of natural antioxidants.

Materials and methods. Alcohol infusions from vegetable raw materials, which were considered on morphological grounds: herbs (35 samples); roots and rhizomes (9 samples); flowers (7 samples); tree bark (2 samples); dried fruits (18 samples); juicy fruits (29 samples). Methods of investigation: redoxmetry determination of antioxidant capacity of from plant raw materials; $p H$-metry.

Results and discussion Infusions of alcohol from vegetable raw materials have a hydrogen index $(\mathrm{pH})$ of 3.13 (Sudanese rose) to 8.17 units $\mathrm{pH}$ (Stinging nettle).

The minimum theoretical value of redox potential $(R P)\left(E h_{\min }\right)$ has a value from $159.1 \mathrm{mV}$ (Stinging nettle) to $370.8 \mathrm{mV}$ (Sudanese rose), and the actual value of $R P\left(E h_{a c t}\right)$ from $\left.8.0 \mathrm{mV}\right)$ up to 308.5 $\mathrm{mV}$ (Quince oblong).

The minimum value of antioxidant (restorative) ability of alcohol infusions $\left(R E_{\text {inf }}\right)$ is for Lemon fruits $-18.8 \mathrm{mV}$, the maximum value of restorative ability - $209.0 \mathrm{mV}$ - for alcohol infusion of Wild strawberry.

The energy of reduction/oxidation of plant raw materials $\left(R E_{\text {plant }}\right)$ relative to the alcohol mixture is in the range of reduction values from $124.5 \mathrm{mV}$ (Wild strawberry leaves) to oxidative values of $-65.7 \mathrm{mV}$ (Lemon fruit).

Alcohol infusions, depending on the activity of plant raw materials have a reducing ability (over $0 \mathrm{mV})-65 \%$ of samples and oxidizing capacity (less than $0 \mathrm{mV}$ ) $-35 \%$ of samples.

The creation of alcoholic tinctures with antioxidant action allows you to bring to market new products that favorably distinguish the range of manufacturers from the range of competitors, creating a positive image of the company.

Conclusion The expansion of the range of alcoholic beverages with the use of alcoholic infusions from plant raw materials to enhance the antioxidant effect is justified. 


\section{Introduction}

One of the promising ways to form consumer properties and expand the range of alcoholic beverages is the use of various compositions of ingredients, food additives and biologically active substances [1-10]. Such substances are designed to improve the organoleptic properties of alcoholic beverages, give them stable therapeutic [11] and prophylactic properties [12].

It is especially important to reduce the toxicity of ethyl alcohol and its impurities, alleviate or eliminate the hangover syndrome, by affecting the metabolism of ethyl alcohol and its impurities in the body [4, 5]. Creating alcoholic beverages with low toxicity [3, 13-15] allows you to bring to market new products that distinguish the manufacturer's range from the range of competitors, creating a favorable image of the company [16], which cares about protecting consumers from the negative effects of alcoholic beverages [3].

Currently, the use of vegetable raw materials in the technology of alcoholic beverages is very relevant [17-19]. Herbal beverages commonly consumed worldwide contain different chemical substances that display a broad spectrum of biological activities [20-22]. They have gained growing interest among scientists and consumers due to their antioxidant properties [23]. The ability of plant phenolics to act as free radical scavengers has led to increased interest in their ability to act as antioxidants $[24,25]$. At present, the antioxidant characteristics of all prescription components, food additives, biologically active substances and their combinations have not been sufficiently studied [26, 27, 28].

$R P$ is an important indicator of the biological activity of solutions [29]. It characterizes the deviation from the ionic balance of free electrons in a liquid medium. Changing the concentration of free electrons leads to a change in its electron charge and, accordingly, the $R P$. If the $R P$ is positive, it indicates the oxidizing ability of the solution, negative indicates recovery ability. The value of $R P$ allows to estimate the energy of processes, that is, characterizes the activity of ions in redox reactions $[30,31]$. Redox reactions affect the ratio of energy to support homeostasis relativity of dynamic constancy of composition and properties of internal environment and stability of basic physiological functions of an organism. This ensures the vital activity of any organism. The magnitude of this rate depends on the ratio and concentration of oxidized and reduced substances in the body, including substances coming from food and beverages, so one of the main factors in the regulation of redox reactions is the $R P[30,31]$.

These circumstances determine the relevance of this work, which is to develop water-alcohol extracts of vegetable raw materials in the technology of alcoholic beverages. Creating alcoholic beverages with reduced toxicity through the introduction of water-alcohol infusions from vegetable raw materials antioxidant properties, allows to create products, which favorably differentiates them from competitors, creating a favorable image of the institution, which cares for the protection of consumers.

At present, the antioxidant characteristics of all prescription components, food additives, biologically active substances and their combinations have not been sufficiently studied.

The aim of the study is to develop the scientific bases of antioxidant activity of water-alcohol infusions from vegetable raw materials and to identify the most promising plants as sources of natural antioxidants.

When achieving this goal, it is necessary to solve the following problems:

- To substantiate the prospect of using water-alcohol infusions from vegetable raw materials in the production of alcoholic beverages;

- To establish the value of the restorative capacity of water-alcohol infusions from vegetable raw materials;

- Identify the most promising sources of natural antioxidants for use in alcoholic beverage technology. 


\section{- Food Technology —}

\section{Materials and methods}

\section{Materials}

100 plant samples were used as objects, which were considered on morphological grounds: herbs (35 samples); roots and rhizomes (9 samples); flowers ( 7 samples); tree bark (2 samples); dried fruits (18 samples); juicy fruits (29 samples). As a control sample used a water-alcohol mixture with a strength of $40 \%$ vol.

\section{Methods of obtaining water-alcohol infusions [3, 15]}

Vegetable raw materials were ground with scissors to a size of $3 \times 3 \mathrm{~mm}$, samples weighing $4 \mathrm{~g}$ were placed in bottles of dark composition, poured $100 \mathrm{ml}$ of a water-alcohol mixture with a strength of $40 \%$ vol. The vials were capped and placed in a Durocell dry air thermostat for 48 hours at $40{ }^{\circ} \mathrm{C}$. The resulting infusions were cooled to room temperature $[3,15]$.

\section{Methods for determining active acidity and $R P[3,15,30]$}

The active acidity index was measured on a $\mathrm{pH}-$ meter «pH-150 MA» with a combined glass electrode «ESC 10601/4». $R P$ was measured on the $\mathrm{pH}-$ meter «pH-150M», in the mode of measuring the potential, with a redoxmetric platinum electrode «ERP-105».

To evaluate the antioxidant properties of the obtained water-alcoholic plant extracts, the method [30], based on the difference of $R P$ in inactivated inorganic solutions and complex biochemical media. The main criteria of this method were its clarity, simplicity, specificity, reproducibility of results and efficiency. A number of researchers also emphasize that method allows to determine the total antioxidant activity of liquid products, including in total in a complex mixture, and multifunctional antioxidants $[3,15]$.

Formula (1) holds for inactivated inorganic solutions in equilibrium. This formula links the active acidity of the $p H$ and the $R P[30]$ :

$$
E h_{\min }=660-60 \cdot p H, \mathrm{mV}
$$

where $E h_{\min }$ - the minimum theoretically expected value of the $R P$; $p H$-active acidity of the test solution.

Acquired meanings of $E h_{\min }$ were compared with the actual measurements of $E h_{a c t}$ of solution. The shift of $R P$ to the side of the recovered meanings - recovery energy $(R E)$ was determined by the formula [30]:

$$
R E=E h_{\text {min }}-E h_{a c t}, \mathrm{mV}
$$

where $R E$ - the shift of $R P$ to the side of recovered meanings (resilence);

$E h_{\min }-$ minimal theoretically expected meaning of $R P$;

$E h_{a c t}-$ actual measured $R P$.

The value of $R P$ allows you to estimate the energy of the processes, i.e. characterizes the activity of ions in redox reactions. 


\section{Research of $R P$ from hydrogen display in infusions of alcohols from vegetable raw materials}

For water-alcohol mixture, the relationship between hydrogen $(p H)$ and $R P(E h)$ was experimentally determined. It is proved that the change of the hydrogen index of the wateralcohol mixture by 1 unit. $\mathrm{pH}$ leads to a change in $R P$ by $42 \mathrm{mV}$ :

$$
E h_{\min }=502-42 \cdot p H, \mathrm{mV}
$$

In the range of values of the hydrogen index of $\mathrm{pH} 2.0-11.0 \mathrm{pH}$ units for the water-alcohol mixture of $R P$ is in the range of $E h_{\min } 418.0-40.0 \mathrm{mV}$.

The obtained values of the $R P$ of the water-alcohol mixture $E h_{\min }$ were correlated with the actually measured values of the $R P$ of alcohol infusions from vegetable raw materials by the platinum electrode $\left(E h_{a c t}\right)$, which characterizes the difference raw materials $\left(R E_{\text {inf }}\right)$ :

$$
R E_{\text {inf }}=E h_{\text {min }}-E h_{\text {act }}, \mathrm{mV}
$$

The energy of reduction/oxidation of vegetable raw materials $\left(R E_{\text {plant }}\right)$ is determined by the difference between the $R P$ of infusions of alcohol from vegetable raw materials $\left(R E_{\text {inf }}\right)$ and solvent (control):

$$
R E_{\text {plant }}=R E_{\text {inf }}-R E_{\text {sol }}, \mathrm{mV}
$$

According to the results of research, an improved method for assessing the antioxidant capacity of infusions of alcohol from vegetable raw materials for the technology of alcoholic beverages.

\section{Results and discussions}

Expansion of the range of alcoholic beverages with the use of alcoholic infusions from vegetable raw materials with increased antioxidant action is substantiated.

Alcohol infusion - a semi-finished product, which is prepared by infusion of vegetable raw materials (both aromatic and non-aromatic) in a water-alcohol mixture [32] with a strength of 40 to $90 \%$ vol.

For the preparation of alcohol infusions used: rectified ethyl alcohol [33-34]; water [26]; vegetable raw materials, which are allowed for use in alcoholic beverages; filter cardboard.

The studies used 100 samples of vegetable raw materials by morphological characteristics [35]: herbs; roots and rhizomes; flowers; tree bark; dried fruits; juicy fruits. As a solvent used a water-alcohol mixture with a strength of $40 \%: p H 5.63$ units $\mathrm{pH} ; E h_{\min } 265.5 \mathrm{mV} ; E h_{a c t}$ $181.0 \mathrm{mV} ; R E_{\text {inf }} 84.5 \mathrm{mV}$; $R E_{\text {plant }} 0.0 \mathrm{mV}$. Sensory evaluation of the control sample are as follows: color - colorless; aroma - alcohol; taste - moderately burning, empty. 


\section{Study of alcoholic infusions of herbs}

35 samples of alcohol infusions from herbs were studied (Figure 1,2). The $p H$ level for alcohol infusions of herbs ranges from 4.53 (Wild strawberry) to 8.17 (Stinging nettle), which have a reaction environment - from acidic to alkaline. The minimum theoretically expected $R P\left(E h_{\text {min }}\right)$ of alcohol infusions of herbs ranges from $159.1 \mathrm{mV}$ (Stinging nettle) to $312.0 \mathrm{mV}$ (Wild strawberry).

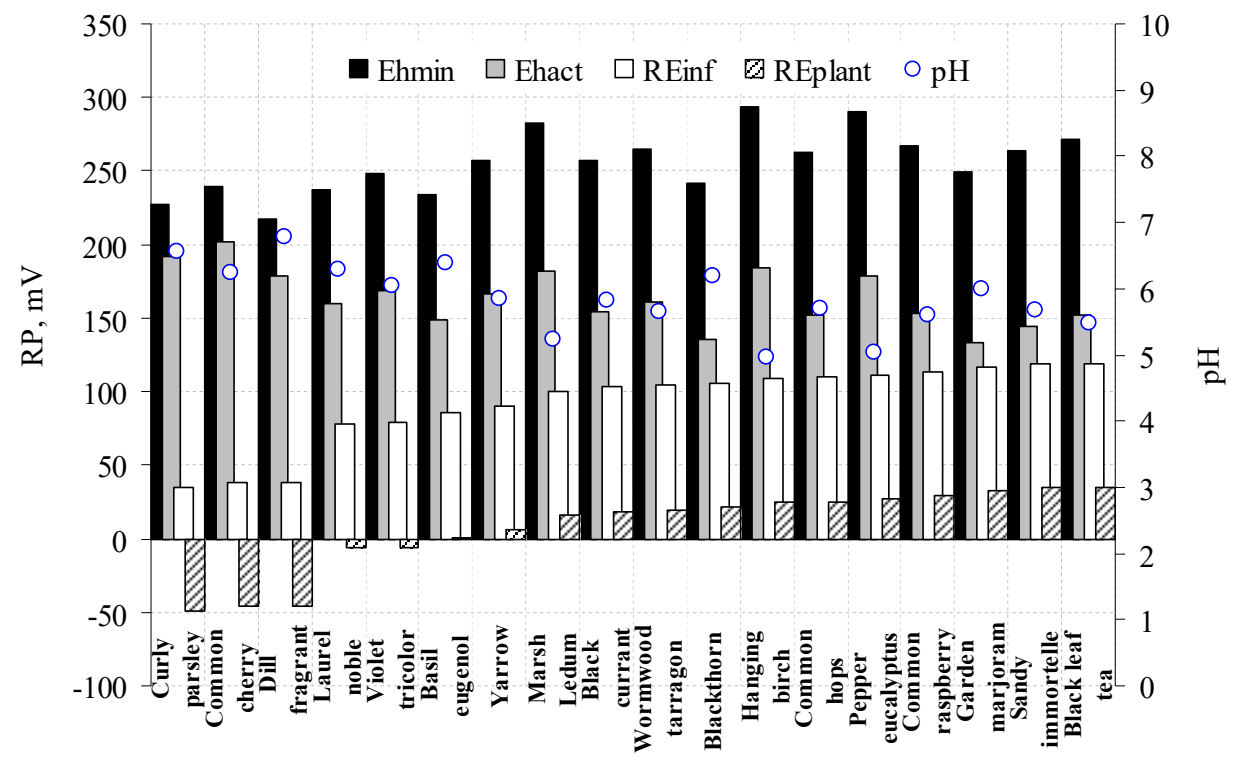

Figure 1. Characteristics of alcohol infusions of herbs

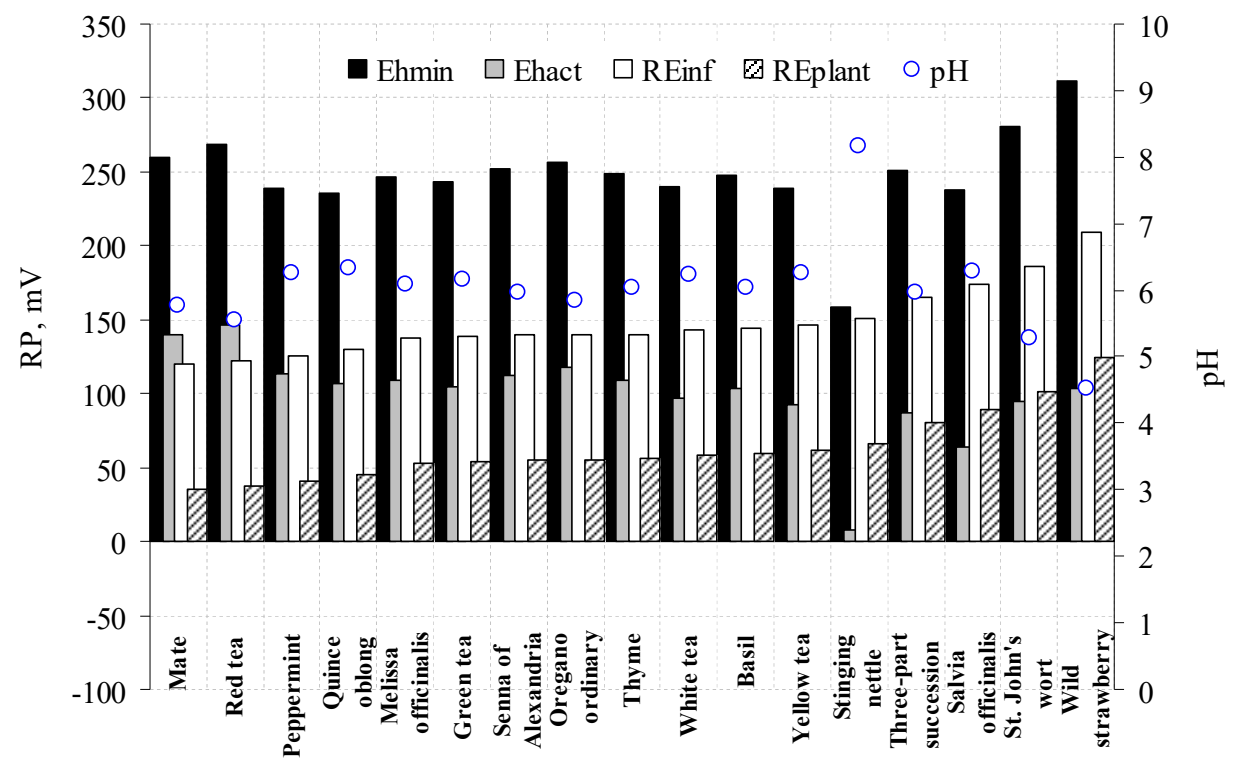

Figure 2. Characteristics of alcohol infusions of herbs 
Actually measured $R P\left(E h_{a c t}\right.$ ) from $8.0 \mathrm{mV}$ (Stinging nettle) to $201.5 \mathrm{mV}$ (Common cherry). At the same time, the minimum value of energy of reduction/oxidation of alcohol infusions $\left(E h_{a c t}\right)-35.4 \mathrm{mV}$ is set for Curly parsley, and the highest $-209.0 \mathrm{mV}$ - for Wild strawberry. The minimum value of energy of reduction/oxidation of vegetable raw materials $\left(R E_{\text {plant }}\right.$ ) is set for Curly parsley «-» $49.1 \mathrm{mV}$ (oxidative values), the maximum value of 124.5 $\mathrm{mV}$ - for Wild strawberry (reduction values).

5 samples of herbs, depending on the energy of reduction/oxidation, have oxidizing characteristics from «-» $49.1 \mathrm{mV}$ (Parsley curly) to «-»» $5.6 \mathrm{mV}$ (Violet tricolor), which is $14 \%$ of all herbs. 30 samples of herbs have regenerative characteristics from $1.0 \mathrm{mV}$ (Basil eugenol) to $124.5 \mathrm{mV}$ (Wild strawberry), which is $86 \%$.

According to sensory evaluation, infusions of alcohol from herbs [47-49] are recommended for use in the production of tinctures, aromatic alcohols, balms, liqueurs [17$19,21,36]$.

Infusions of alcohol from Wild strawberry have received the greatest value of antioxidant activity; sensory evaluations of the product: color - deep brown; aroma - herbal; taste - soft, tart, sour, which is recommended for use in alcoholic beverages for tinctures and balms.

\section{Research of alcoholic infusions from roots and rhizomes}

9 samples of alcohol infusions from roots and rhizomes were studied. The $p H$ level for infusions of alcohol from the roots and rhizomes is from 3.87 (Garden onion) to 6.86 (Carrot), i.e. infusions of alcohol have an acidic reaction, which is close to neutral (Figure $3)$.

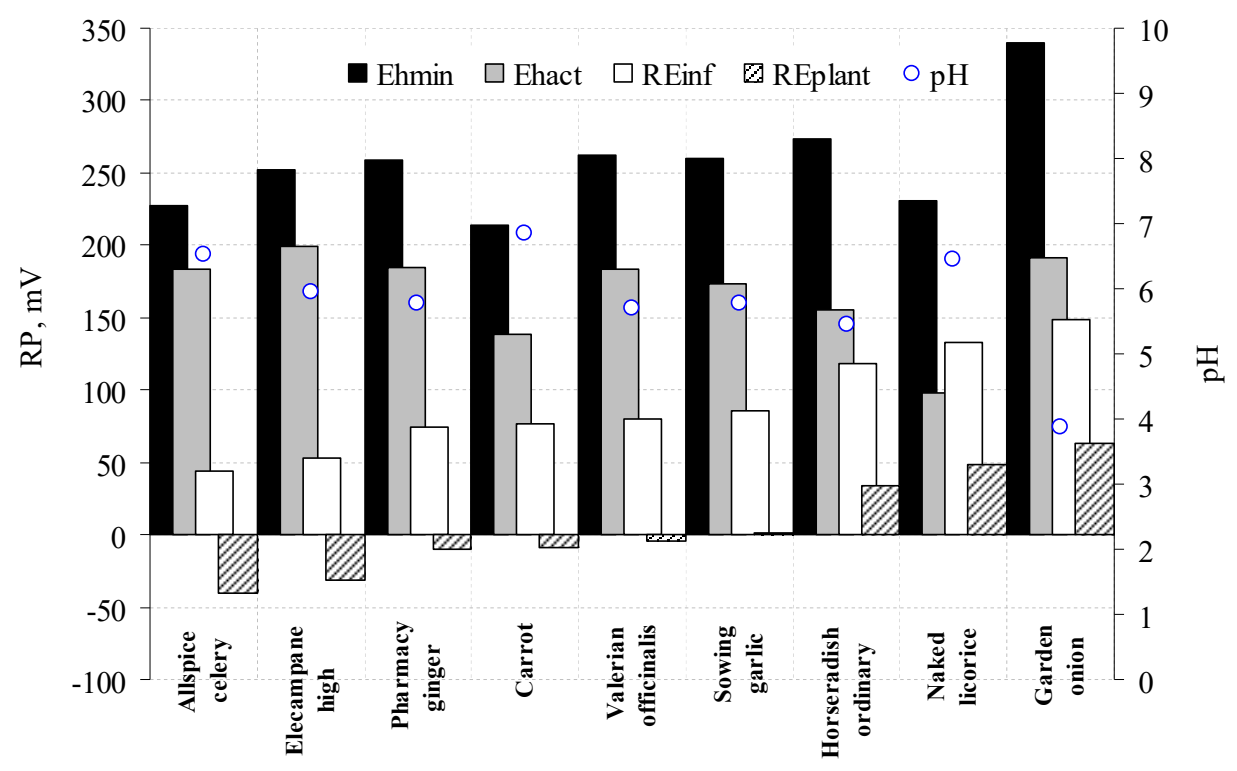

Figure 3. Characteristics of alcohol infusions from the roots and rhizomes 
The minimum theoretically expected $R P\left(E h_{\min }\right)$ for alcohol infusions from roots and rhizomes ranges from $214.1 \mathrm{mV}$ (Carrot) to $339.7 \mathrm{mV}$ (Garden onion), and the actually measured $R P\left(E h_{a c t}\right)$ - from $98.0 \mathrm{mV}$ (Naked licorice) to $199.0 \mathrm{mV}$ (Elecampane high). At the same time, the minimum value of energy of reduction/oxidation of alcohol infusions $\left(R E_{i n f}\right)$ is characteristic of Allspice celery and is equal to $44.0 \mathrm{mV}$, and the highest value $148.2 \mathrm{mV}$ has an alcoholic infusion of Garden onion. The minimum value of energy of reduction/oxidation of vegetable raw materials $\left(R E_{\text {plant }}\right)$ is set for Allspice celery «-» $40.5 \mathrm{mV}$ (oxidative values), the maximum value of $63.7 \mathrm{mV}$ - for Garden onion (reducing values).

In the group of plant raw materials roots and rhizomes were identified: plants with oxidative values of 5 samples ( $56 \%$ ); plants with restorative values - 4 samples (44\%).

When assessing the sensory evaluations of alcohol infusions from the roots and rhizomes of 3 samples (Elecampane high, Valerian officinalis, Garden onion) - it is not recommended to use for alcoholic beverages, due to their aroma and taste [37, 38]. Thus, Elecampane high has an unpleasant taste (soapy, sour-bitter, obsessive), alcohol infusion of valerian has an unpleasant (Valerian officinalis) aroma and tastes burning, sour, with an unpleasant aftertaste; infusion of alcohol from Garden onion has an unpleasant onion (nitrogencontaining compounds) aroma and tart taste. Sensory evaluations of the proposed (possible) options for the use of infusions of alcohol from the roots and rhizomes gives grounds not to offer for use in alcoholic beverages samples even with maximum antioxidant characteristics (for example, Garden onion with a high regenerative activity of $63.7 \mathrm{mV}$ ).

\section{Research of infusions of alcohol from flowers}

From the group flowers 7 samples were studied. The $p H$ level for infusions of alcohol from flowers has a reaction of the environment from 3.13 (Sudanese rose) to 5.98 (Chamomile officinalis), i.e. infusions of alcohol from flowers have an acid reaction (Figure 4).

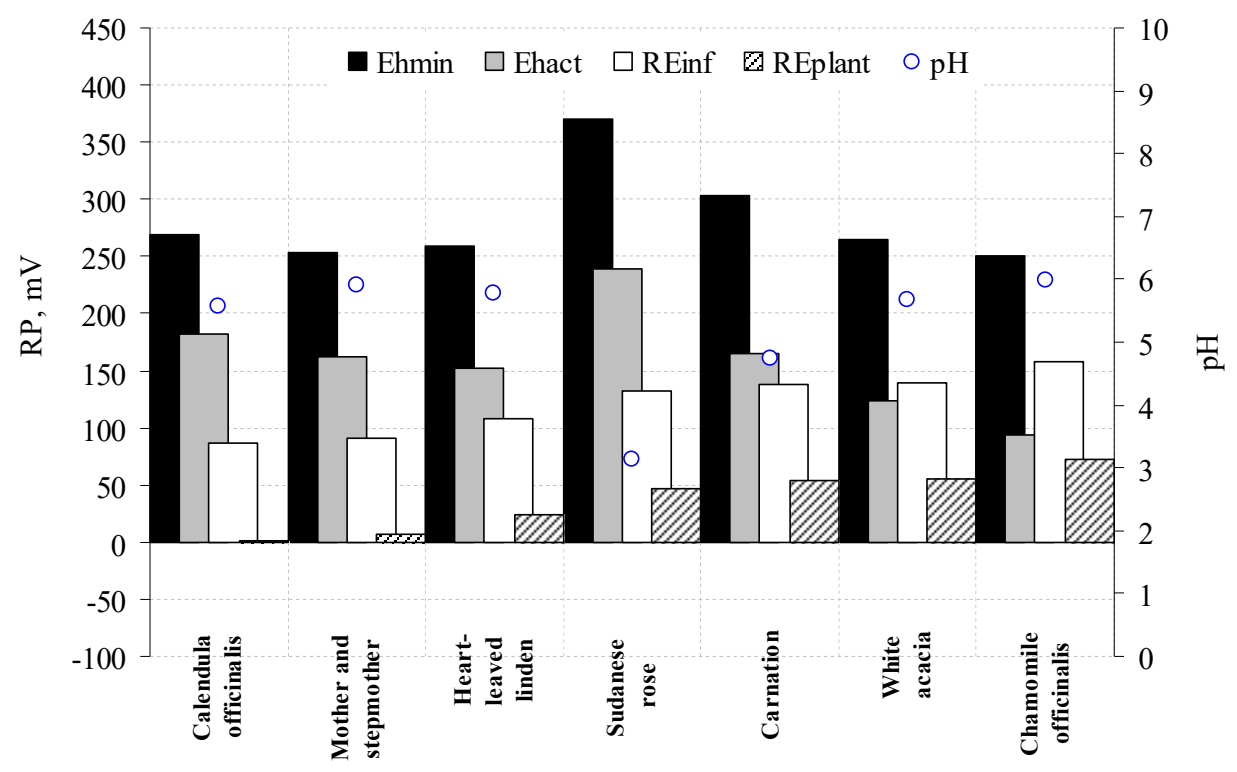

Figure 4. Characteristics of alcoholic infusions of flowers 
The minimum theoretically expected $R P\left(E h_{\min }\right)$ for infusions of alcohol from the flowers is from $251.1 \mathrm{mV}$ (Chamomile officinalis) to $370.8 \mathrm{mV}$ (Sudanese rose), and the actually measured $R P\left(E h_{a c t}\right)$ - from $93.5 \mathrm{mV}$ (Chamomile officinalis) to $239.0 \mathrm{mV}$ (Sudanese rose). The minimum value of the energy of reduction/oxidation of alcohol infusions $\left(R E_{\text {inf }}\right)$ is characteristic of Calendula officinalis and is equal to $86.0 \mathrm{mV}$, and the highest value $157.6 \mathrm{mV}$ has an alcoholic infusion of Chamomile officinalis. The minimum value of energy of reduction/oxidation of vegetable raw materials $\left(R E_{p l a n t}\right)$ is set for Calendula officinalis 1.5 $\mathrm{mV}$ (reducing values), the maximum value of $73.1 \mathrm{mV}$ - for Chamomile officinalis (reducing values) $[38,39]$.

According to sensory evaluations, infusions of alcohol from flowers are recommended for use in the production of tinctures, aromatic alcohols, balms, liqueurs.

\section{Research of alcohol infusions from tree bark}

From the group tree bark 2 samples were studied. The $p H$ level for infusions of alcohol Cinnamon (Cinnamon bark) is 5.34 and Rooibus -5.52 units $p H$. The minimum theoretically expected $R P\left(\mathrm{Eh}_{\min }\right)$ is $277.9 \mathrm{mV}$ (Cinnamon) and $270.2 \mathrm{mV}$ (Rooibus), the actually measured $R P\left(E h_{a c t}\right)$ is $208.5 \mathrm{mV}$ and $155.0 \mathrm{mV}$, respectively. At the same time, the minimum value of energy of reduction/oxidation of vegetable raw materials $\left(R E_{\text {plant }}\right)$ is equal to 69.4 $\mathrm{mV}$ and $115.0 \mathrm{mV}$, respectively (Figure 5).

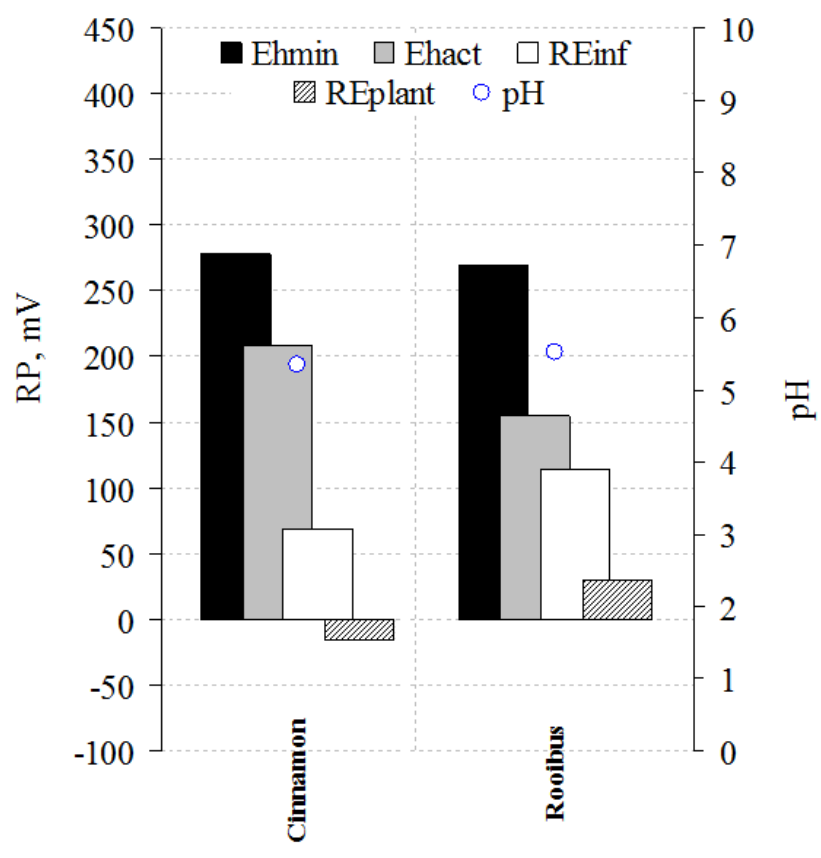

Figure 5. Characteristics of alcohol infusions from bark

According to sensory evaluations, infusions of alcohol from the bark are recommended for use in the production of tinctures, aromatic alcohols, balms. 


\section{Research of infusions of alcohol from dried fruits}

In the group dried fruits 18 samples were studied. The $p H$ level of infusions of alcohol from dried fruits (Figure 6) ranges from 4.48 (Badian real) to 6.82 (Horse chestnut), i.e. infusions of alcohol from dried fruits has an acidic environment that is close to neutral.

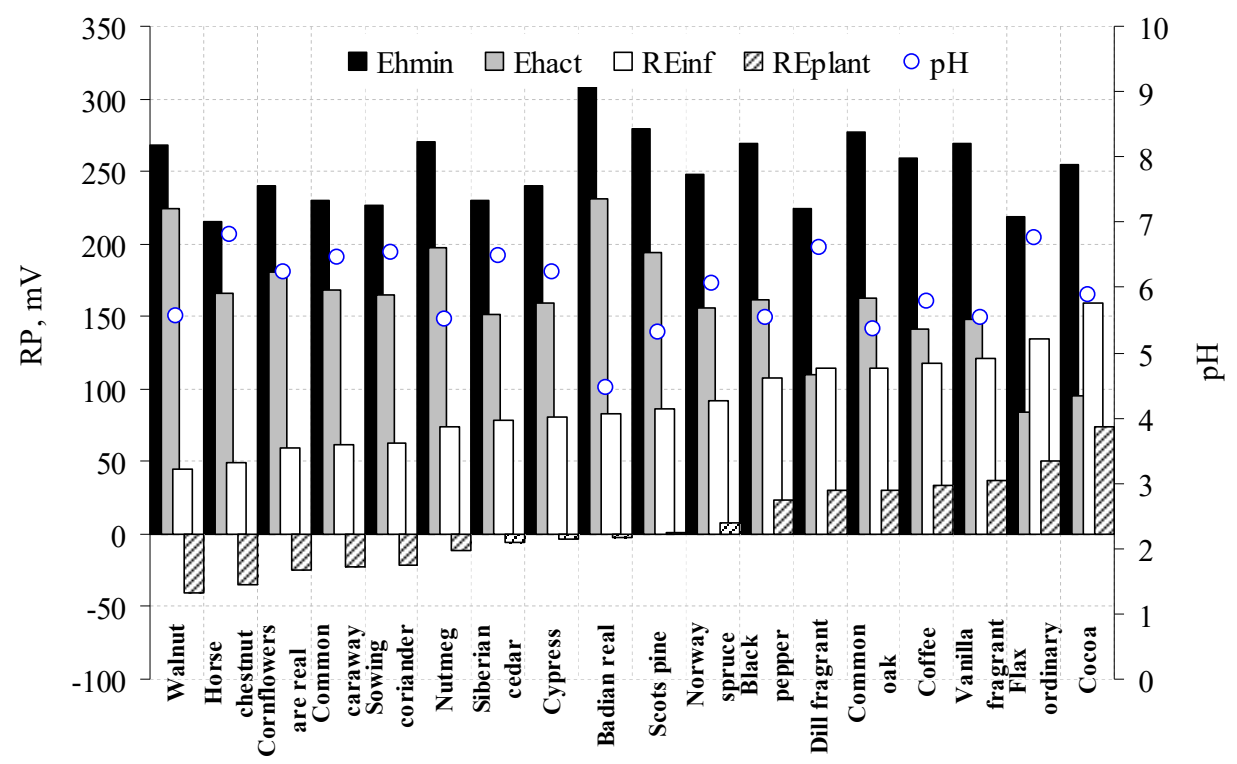

Figure 6. Characteristics of alcoholic infusions of dried fruits

The minimum theoretically expected $R P\left(E h_{\min }\right)$ for infusions of alcohol from dried fruits has a value from $215.6 \mathrm{mV}$ (Horse chestnut), to $314.1 \mathrm{mV}$ (Badian real), the actually measured $R P\left(E h_{a c t}\right)$ - from $83.5 \mathrm{mV}$ (Flax ordinary) to $231.5 \mathrm{mV}$ (Badian real). The minimum value of the energy of reduction/oxidation of alcohol infusions $\left(R E_{\text {inf }}\right)$ is typical for Walnuts [40] $-44.5 \mathrm{mV}$, and the highest value $-158.9 \mathrm{mV}$ has an alcoholic infusion of Cocoa. The minimum value of energy of reduction/oxidation of vegetable raw materials $\left(R E_{\text {plant }}\right)$ is set for Walnut «-» $40.0 \mathrm{mV}$ (oxidative values), the maximum value of $74.4 \mathrm{mV}-$ for Cocoa (reduction values).

9 samples of dried fruits, depending on the energy of reduction/oxidation, have oxidizing characteristics from «-» $40.0 \mathrm{mV}$ (Walnut) [41] to «-» $1.9 \mathrm{mV}$ (Badian real), which is $50 \%$ of all dry fruits. 9 samples of dried fruits have restorative characteristics from $1.4 \mathrm{mV}$ (Scots pine) [42] to $74.4 \mathrm{mV}$ (Cocoa), which is $50 \%$.

According to the sensory evaluations of 18 studied samples of alcoholic infusions of dried fruits - 1 sample (Flax ordinary) - is not recommended for use in the production of alcoholic beverages due to the aroma and taste (aroma of vegetable oil with a bitter taste).

\section{Research of alcohol infusions from juicy fruits}

In the group juicy fruits [33, 34] 29 samples were studied (Figure 7, 8). The $p H$ level of infusions of alcohol from juicy fruits has an acidic environment, approaching neutral and varies from 3.60 (Black currant) to 6.77 (Sowing cucumber). 


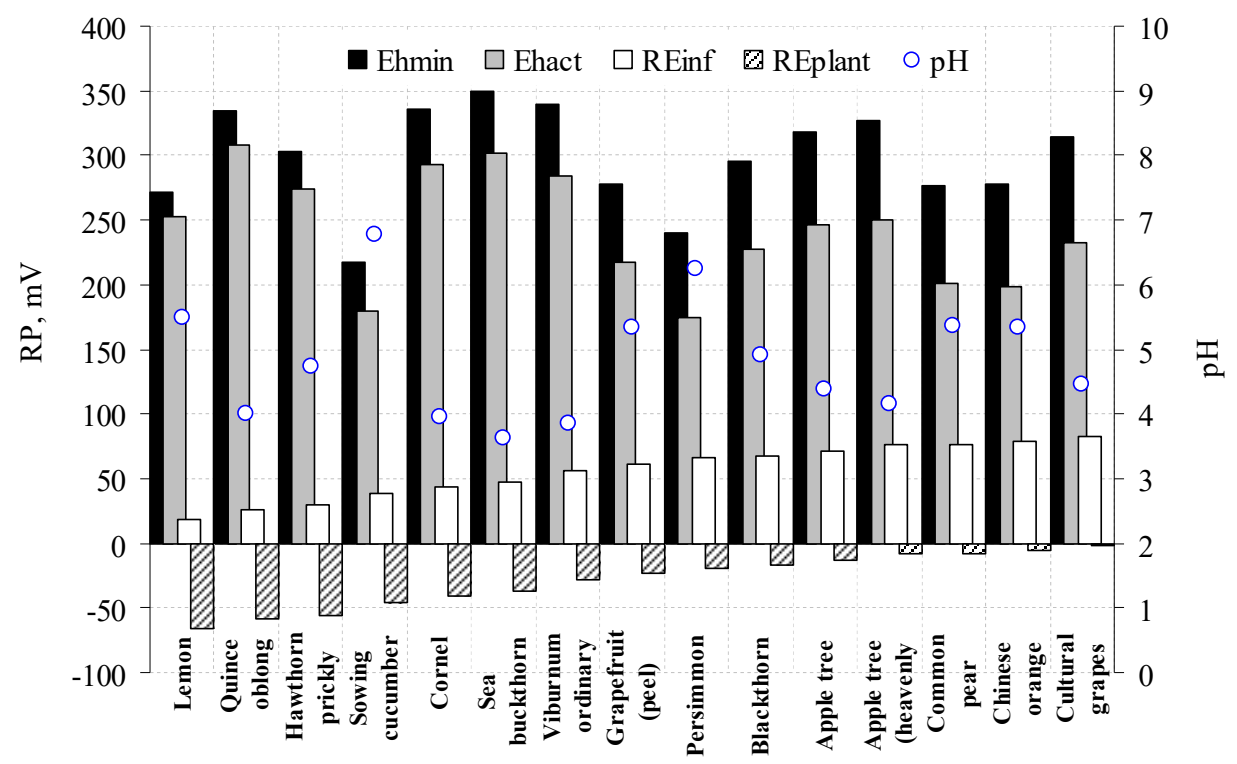

Figure 7. Characteristics of alcoholic infusions of juicy fruits

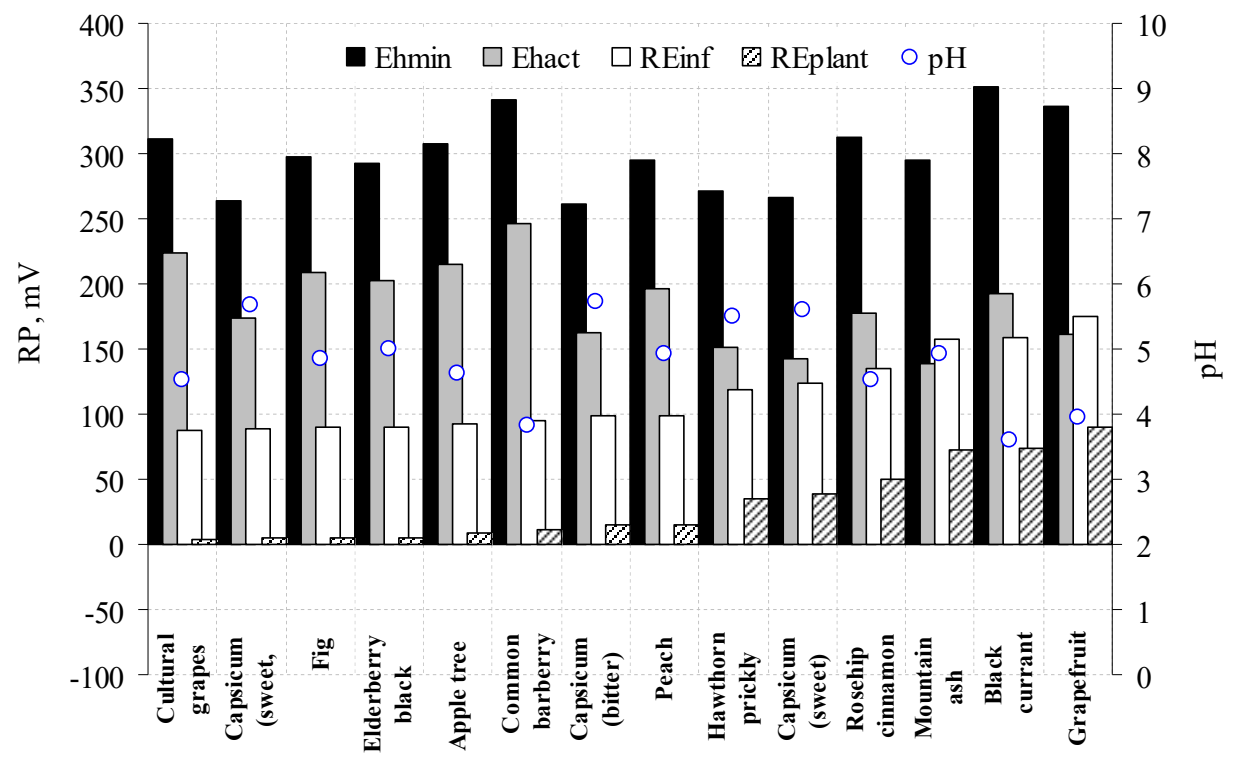

Figure 8. Characteristics of alcoholic infusions of juicy fruits 
The minimum theoretically expected $R P\left(E h_{\min }\right)$ for alcoholic infusions of juicy fruits is from $217.9 \mathrm{mV}$ (Sowing cucumber), to $351.0 \mathrm{mV}$ (Black currant), the actually measured $R P\left(E h_{a c t}\right)$ - from 138,5 mV (Mountain ash) to $308.5 \mathrm{mV}$ (Quince oblong). The minimum value of the energy of reduction/oxidation of alcohol infusions $\left(R E_{i n f}\right)$ is typical for Lemon $18.8 \mathrm{mV}$, and the highest value $-174.8 \mathrm{mV}$ has an infusion of alcohol Grapefruit. The minimum value of energy of reduction/oxidation of vegetable raw materials $\left(R E_{\text {plant }}\right)$ is set for Lemon «-» $65.7 \mathrm{mV}$ (oxidative values), the maximum value of $90.3 \mathrm{mV}$ - for Grapefruit (reduction values).

15 samples of juicy fruits, depending on the energy of reduction/oxidation, have oxidizing characteristics from «-» $65.7 \mathrm{mV}$ (Lemon) to «-» $2.2 \mathrm{mV}$ (Grapes), which is $52 \%$ of all juicy fruits. 14 samples of juicy fruits have restorative characteristics from $3.5 \mathrm{mV}$ (Grapes raisins) to $90.3 \mathrm{mV}$ (Grapefruit), which is $48 \%$.

According to sensory evaluations, all infusions of alcohol from juicy fruits except infusion of Figs and Raisins are recommended for use in the production of tinctures, aromatic alcohols, balms, liqueurs. When examined in juicy fruits, a negative aroma of sulfur dioxide was detected, which is used for processing, in order to increase their shelf life.

It can be concluded that infusions of alcohol from vegetable raw materials have a hydrogen index of 3.13 (Sudanese rose) to 8.17 units $\mathrm{pH}$ (Stinging nettle). The minimum theoretical value of $R P\left(E h_{\min }\right)$ has a value from $159.1 \mathrm{mV}$ (Stinging nettle) to $370.8 \mathrm{mV}$ (Sudanese rose), and the actual value of $R P\left(E h_{a c t}\right)$ from $8.0 \mathrm{mV}$ (Stinging nettle) up to 308.5 $\mathrm{mV}$ (Quince oblong). The minimum value of antioxidant (restorative) ability of alcohol infusions $\left(R E_{\text {inf }}\right)$ is for lemon fruits $-18.8 \mathrm{mV}$, the maximum value of restorative ability $209.0 \mathrm{mV}$ - for alcohol infusion of Wild strawberry. It is proved that the energy of reduction/oxidation of plant raw materials $\left(R E_{\text {plant }}\right)$ relative to the alcohol mixture is in the range of reduction values from $124.5 \mathrm{mV}$ (Wild strawberry leaves) to oxidative values of «$» 65.7 \mathrm{mV}$ (Lemon fruit). It was found that alcohol infusions, depending on the activity of plant raw materials have a reducing ability (over $0 \mathrm{mV}$ ) $-65 \%$ of samples and oxidizing capacity (less than $0 \mathrm{mV}$ ) $-35 \%$ of samples.

\section{Conclusions}

1. The expansion of the range of alcoholic beverages with the use of alcoholic infusions from plant raw materials to improve sensory evaluations and enhance the antioxidant effect is justified. A study of alcohol infusions from vegetable raw materials, which were considered on morphological grounds: herbs ( 35 samples); roots and rhizomes ( 9 samples); flowers (7 samples); tree bark (2 samples); dried fruits (18 samples); juicy fruits (29 samples).

2. Infusions of alcohol from vegetable raw materials have a hydrogen index from 3.13 (Sudanese rose) to 8.17 units $\mathrm{pH}$ (Stinging nettle). The minimum theoretical value of $R P\left(E h_{\text {min }}\right)$ is from $159.1 \mathrm{mV}$ (Stinging nettle) to $370.8 \mathrm{mV}$ (Sudanese rose) and the actual value of $R P\left(E h_{a c t}\right)$ from $8.0 \mathrm{mV}$ (Stinging nettle) up to $308.5 \mathrm{mV}$ (Quince oblong). The minimum value of antioxidant (restorative) ability of alcohol infusions $\left(R E_{\text {inf }}\right)$ is for Lemon fruits $-18.8 \mathrm{mV}$, the maximum value of restorative ability -209.0 $\mathrm{mV}$ - for alcohol infusion of Wild strawberry. It is proved that the energy of reduction/oxidation of vegetable raw materials $\left(R E_{\text {plant }}\right)$ relative to water-alcohol mixtures is in the range of reduction values from $124.5 \mathrm{mV}$ (Wild strawberry leaves) to oxidative values of $-65.7 \mathrm{mV}$ (Lemon fruit). 
3. Alcohol infusions, depending on the activity of plant raw materials have a reducing ability (over $0 \mathrm{mV}$ ) $-65 \%$ of samples and oxidizing capacity (less than $0 \mathrm{mV}$ ) $-35 \%$ of samples. The creation of alcoholic beverages with antioxidant action allows you to bring to market new products that favorably distinguish the range of manufacturers from the range of competitors, creating a positive image of the company.

\section{References}

1. Shujuan T.S., Li L., Xiao Z., Wu Y., Zhang Z. (2005), Pervaporation of alcoholic beverages - the coupling effects between ethanol and aroma compounds, Journal of Membrane Science, 264, pp. 129-136.

2. Veljović S., Nikićević N., Nikšić M. (2019), Medicinal Fungus Ganoderma lucidum as Raw Material for Alcohol Beverage Production, Alcoholic Beverages, 7, pp. 161-197.

3. Kuzmin O., Kucherenko V., Sylka I., Isaienko V., Furmanova Y., Pavliuchenko E., Hubenia V. (2020), Antioxidant capacity of alcoholic beverages based on infusions from nontraditional spicy-aromatic vegetable raw materials, Ukrainian Food Journal, 9 (2), $404-424$.

4. Bautista A.P. (2002), Chronic alcohol intoxication primes Kupffer cells and endothelial cells for enhanced CC-chemokine production and concomitantly suppresses phagocytosis and chemotaxis, Front Biosci., 7, pp. 117-125.

5. Bautista A.P. (1997), Chronic alcohol intoxication induces hepatic injury through enhanced macrophages inflammatory protein-2 production and intercellular adhesion molecule-1 expression in the liver, Hepatology, 25, pp. 335-342.

6. Bonnaffoux H., Roland A., Schneider R., Cavelier F. (2020), Spotlight on release mechanisms of volatile thiols in beverages, Food Chemistry, 339, March.

7. Pielech-Przybylska K., Balcerek M. (2019), New Trends in Spirit Beverages Production, Alcoholic Beverages, 7, pp. 65-111.

8. Ryan R. (2014), Safety of Food and Beverages: Alcoholic Beverages, Encyclopedia of Food Safety, 3, pp. 364-370.

9. Dasgupta A. (2019), Chapter 1 - Alcohol: Pharmacokinetics, Health Benefits With Moderate Consumption and Toxicity, Critical Issues in Alcohol and Drugs of Abuse Testing (Second Edition), pp. 1-16.

10. Shankar K., Mehendale H.M. (2014), Alcoholic Beverages and Health Effects, Encyclopedia of Toxicology (Third Edition), pp. 120-122.

11. Condea R., Corrêaa V., Carmonab F., Continic S., Pereirac A. (2011), Chemical composition and therapeutic effects of Lippia alba (Mill.) N. E. Brown leaves hydro-alcoholic extract in patients with migraine, Phytomedicine, 18, pp. 1197-1201.

12. Shirwaikar A., Rajendran K., Punitha I.S.R. (2005), Antidiabetic activity of alcoholic stem extract of Coscinium fenestratum in streptozotocin-nicotinamide induced type 2 diabetic rats, Journal of Ethnopharmacology, 97, pp. 369-374.

13. Ascrizzi R., Iannone M., Cinque G., Marianelli A., Pistelli L., Flamini G. (2020), «Hemping» the drinks: Aromatizing alcoholic beverages with a blend of Cannabis sativa L. flowers, Food Chemistry, vol. 325, September.

14. Lopes A.C.A., Eda S.H., Andrade R.P., Amorim J.C., Duarte W.F. (2019), New Alcoholic Fermented Beverages - Potentials and Challenges, Fermented Beverages, vol. 5: The Science of Beverages, pp. 577-603.

15. Kuzmin O., Kovalchuk Y., Velychko V., Romanchenko N. (2016), Improvement technologies of aqueous-alcoholic infusions for the production of syrups, Ukrainian Journal of Food Science, 4(2), pp. 258-275.

16. Kuzmin O., Levkun K., Riznyk A. (2017), Qualimetric assessment of diets, Ukrainian Journal of Food Science, 6(1), pp. 46-60. 
17. Andreou V., Strati I.F., Fotakis C., Liouni M., Sinanoglou V.J. (2018), Herbal distillates: A new era of grape marc distillates with enriched antioxidant profile, Food Chemistry, 253, pp. 171-178.

18. Iannitti T., Palmieri B. (2009), Antioxidant therapy effectiveness: an up to date, European Review for Medical and Pharmacological Sciences, 13, pp. 245-278.

19. Kawa-Rygielska J., Adamenko K., Kucharska A.Z., Szatkowska K. (2019), Fruit and herbal meads - Chemical composition and antioxidant properties, Food Chemistry, 283, pp. 1927.

20. Frolova N., Ukrainets A., Sylka I., Nemirich A., Kuzmin O. (2019), Separation of terpenes from lemon essential oil by selective fractionation under a vacuum, Eastern-European Journal of Enterprise Technologies, 2/11(98), pp. 32-36.

21. Pyrzynska K., Sentkowska A. (2019), Herbal Beverages as a Source of Antioxidant Phenolics, Natural Beverages, 13, pp. 125-142.

22. Sentkowska A., Pyrzynska K. (2018), Investigation of antioxidant interaction between Green tea polyphenols and acetaminophen using isobolographic analysis, Journal of Pharmaceutical and Biomedical Analysis, 15910, pp. 393-397.

23. Breiter T., Laue C. Kressel G., Gröll S., Hahn A. (2011), Bioavailability and antioxidant potential of rooibos flavonoids in humans following the consumption of different rooibos formulations, Food Chemistry, 128(215), pp. 338-347.

24. Keating L., Hayes J., Moane S., Lehane M., Furey A. The effect of simulated gastrointestinal conditions on the antioxidant activity of herbal preparations made from native Irish hawthorn. Journal of Herbal Medicine, 4(3). 2014. pp. 127-133.

25. Herrera T., Aguilera Y., Rebollo-Hernanz M., Bravo E., Martín-Cabrejas M.A. (2018), Teas and herbal infusions as sources of melatonin and other bioactive non-nutrient components, $L W T, 89$, pp. 65-73.

26. Buglass A.J., Caven-Quantrill D.J. (2012), Applications of natural ingredients in alcoholic drinks, Natural Food Additives, Ingredients and Flavourings, pp. 358-416.

27. Gulua L., Nikolaishvili L., Jgenti M., Turmanidze T., Dzneladze G. (2018), Polyphenol content, anti-lipase and antioxidant activity of teas made in Georgia, Annals of Agrarian Science, 16 (3), pp. 357-361.

28. Joubert E., Beer D. (2012), Phenolic content and antioxidant activity of rooibos food ingredient extracts, Journal of Food Composition and Analysis, 27(1). pp. 45-51.

29. Merwe J.D., Beer D., Swanevelder S., Joubert E., Gelderblom W.C.A. (2017), Dietary exposure to honeybush (Cyclopia) polyphenol-enriched extracts altered redox status and expression of oxidative stress and antioxidant defense-related genes in rat liver, South African Journal of Botany, 110, pp. 230-239.

30. Priluckij V.I. (1997), Okislitel'no-vosstanovitel'nyj potencial dlja harakteristiki protivokislitel'noj aktivnosti razlichnyh napitkov i vitaminnyh komponentov, Jelektrohim. aktivacija v medicine, sel. hozjajstve, prom-sti: I Mezhdunar. Simpozium.

31. Bahir V.M. (1999), Sovremennye tehnicheskie jelektrohimicheskie sistemy dlja obezzarazhivanija, ochistki i aktivirovanija vody, VNIIIMT.

32. Aylott R.I. (2016), Vodka, Encyclopedia of Food and Health, pp. 442-445.

33. Aylott R. (2013), Analytical Strategies Supporting Protected Designations of Origin for Alcoholic Beverages, Comprehensive Analytical Chemistry, 60, pp. 409-438.

34. Bekatorou A. (2016), Alcohol: Properties and Determination, Encyclopedia of Food and Health, pp. 88-96.

35. Rakhmetov D.B. (2011), Teoretychni ta prykladni aspekty introduktsiyi roslyn $v$ Ukrayini, Kiev: Ahrar Media Crup.

36. Juárez-Gómez J., Ramírez-Silva M.T., Guzmán-Hernández D.S., Romero-Romo M., Palomar-Pardavé M. (2020), Novel electrochemical method to evaluate the antioxidant capacity of infusions and beverages, based on in situ formation of free superoxide radicals, 
Food Chemistry, 332, 127409.

37. Mariod A.A. (2016), Effect of Essential Oils on Organoleptic (Smell, Taste, and Texture) Properties of Food, Essential Oils in Food Preservation, Flavor and Safety, pp. 131-137.

38. Jabri M-A., Aissani N., Tounsi H., Sakly M., Marzouki L., Sebai H. (2017), Protective effect of Chamomile officinalis (Matricaria recutita L.) decoction extract against alcohol-induced injury in rat gastric mucosa, Pathophysiology, 24(1), pp. 1-8.

39. Agatonovic-Kustrin S., Ortakand D.B., Mortona D.W., Yusof A.P. (2015), Rapid evaluation and comparison of natural products and antioxidant activity in Calendula officinalis, feverfew, and German Chamomile officinalis extracts, Journal of Chromatography A, 1385, pp. 103-110.

40. Simsek M., Süfer Ö. (2020), Infusion of walnut (Juglans regia L.) shell tea: multi response optimization and antioxidant potential, [Online], available at: https://www.sciencedirect.com/journal/journal-of-applied-research-on-medicinal-andaromatic-plants/articles-in-press (Available online 2 November 2020).

41. Fernández-Agullóa A., Pereira E., Freire M.S., Valentão P., Andrade P.B., GonzálezÁlvarez J., Pereira J.A. (2013), Influence of solvent on the antioxidant and antimicrobial properties of walnut (Juglans regia L.) green husk extracts, Industrial Crops and Products, 42, pp. 126-132.

42. Jeong M.S., Park S., Han E.J., Park S.Y., Kim M.J., Jung K., Choa S.-H., Seo- Kim S.-Y., Yoon W.-J., Ahn G., Kim K.-N. (2020), Pinus thunbergii PARL leaf protects against alcohol-induced liver disease by enhancing antioxidant defense mechanism in BALB/c mice, Journal of Functional Foods, 73.

43. Nour V., Stampar F., Veberic R., Jakopic J. (2013), Anthocyanins profile, total phenolics and antioxidant activity of black currant ethanolic extracts as influenced by genotype and ethanol concentration, Food Chemistry, 141 (2), pp. 961-966.

44. Lapornik B., Prošek M., Wondra A.G. (2005), Comparison of extracts prepared from plant by-products using different solvents and extraction time, Journal of Food Engineering, 71(2), pp. 214-222.

45. Wen H., Hsu Yu-I., Asoh Taka-Aki, Uyama H. (2020), Antioxidant activity and physical properties of $\mathrm{pH}$-sensitive biocomposite using poly(vinyl alcohol) incorporated with green tea extract, Polymer Degradation and Stability, 178, 109215.

46. Rodrigues M.J., Neves V., Martins A., Rauter A.P., Neng N.R., Nogueira J.M.F., Varela J., Barreira L., Custódio L. (2016), In vitro antioxidant and anti-inflammatory properties of Limonium algarvense flowers' infusions and decoctions: A comparison with green tea (Camellia sinensis), Food Chemistry, 200, pp. 322-329.

47. Halliwell B., Gutteridge J.M.C. (1990), The antioxidants of human extracellular fluids, Archives of Biochemistry and Biophysics, 280, pp. 1-8.

48. Chandrasekara A., Shahidi F. (2018), Herbal beverages: Bioactive compounds and their role in disease risk reduction - A review, Journal of Traditional and Complementary Medicine, 8(4), pp. 451-458.

49. Fotakis C., Tsigrimani D., Tsiaka T., Lantzouraki D.Z., Zoumpoulakis P. (2016), Metabolic and antioxidant profiles of herbal infusions and decoctions, Food Chemistry, 211, pp. 963971. 